\title{
Restauração de dente molar 209 como tratamento de cárie infundibular em equino - relato de caso
}

[a] Universidade Luterana do Brasil (ULBRA), Canoas, RS, Brasil

[b] Equident - Odontologia Equina Avançada, Porto Alegre, RS, Brasil

[c] Universidade de Santa Cruz do Sul (UNISC), Santa Cruz, RS, Brasil

*Autor correspondente

e-mail: lizzie.dietrich@gmail.com

\section{Resumo}

Cáries dentárias são frequentes em cavalos velhos e animais em regime de arraçoamento intensivo. Pode também ocorrer pela decomposição de alimentos ou por ação de enzimas bacterianas. A cárie é causada pela ação de um ácido, que provem da decomposição da comida pela ação das bactérias que habitam a boca, e provoca a erosão do esmalte e sua posterior corrosão. A principal bactéria responsável pela cárie em humanos é o Streptococcus mutans, bactéria com capacidade acidogênica e acidúrica. Os equinos afetados pela cárie apresentam dificuldade de apreensão e mastigação, além de halitose característica. 0 tipo mais comum de cárie dental nesta espécie é a que afeta o infundíbulo do dente maxilar, que pode ser observada com maior prevalência em animais com mais de 12 anos de idade. Estes dentes molares maxilares são mais predispostos aos processos cariogênicos devido à presença da hipoplasia de cemento infundibular, ou seja, deposição deficiente de cemento no interior do infundíbulo. 0 presente trabalho relata o atendimento de rotina em um equino da raça Brasileiro de Hipismo, fêmea, 15 anos de idade, sem histórico e sinais clínicos relacionados. Durante o tratamento dental de rotina, a inspeção intraoral, sob sedação e com uso de espelho e sonda exploratória, observou-se acúmulo de alimento no dente Triadan 209, na região infundibular, e perda da estrutura anatômica dos infundíbulos rostral e caudal. Radiografia não revelou alteração do dente afetado, tampouco no seu ápice. Somado ao quadro clínico assintomático e à presença de alimento impactado no infundíbulo, chegou-se ao diagnóstico de cáries infundibulares (rostral e caudal) de grau 3 (segundo Dacre), possivelmente em consequência de hipoplasia de cemento infundibular. 0 tratamento foi a restauração infundibular do dente 209, a fim de manter as características anatômicas e funcionais do elemento dentário e evitar a proliferação da cárie e, consequentemente, uma fratura ou infecção apical. 0 procedimento de 
restauração foi realizado com o equino em estação, sob sedação em bolus com detomidina $0,02 \mathrm{mg} / \mathrm{kg}$ e dose de suplementação $0,01 \mathrm{mg} / \mathrm{kg}$ associado ao butorfanol $0,01 \mathrm{mg} / \mathrm{kg}$. 0 tratamento primordial para esta doença incluiu o nivelamento das arcadas e retirada da oclusão do dente afetado e enfraquecido. No procedimento de restauração foi efetuada a limpeza dos infundíbulos cariados do dente 209 com lavagem com solução de clorexidina $0,2 \%$, intercalada com curetagem usando curetas de dentina adaptadas de diferentes angulações, com a intenção de remover a matéria orgânica. Após esta limpeza inicial, usou-se broca de carbide esférica e motor de baixa rotação para a raspagem das paredes infundibulares e remoção de tecido cariado. A etapa seguinte consistiu na aplicação de cariostático (removedor químico de cárie à base de ácido fluorídrico), aguardando-se 1 minuto para prosseguir com o enxágue e secagem, seguido do uso de hidróxido de cálcio fotopolimerizável. Continuou-se a restauração com aplicação de ionômero de vidro também fotopolimerizável. Logo em seguida, foi aplicado ataque ácido por 30 segundos e enxague. Por fim, foi feita a aplicação de um adesivo odontológico para aderência da resina. A última etapa consistiu no uso da resina dual core, seguida de fotopolimerizador para promover a cura inicial. Como pós-operatório foi utilizado flunixin meglumine 2,2 mg/kg SID, IV, por três dias. 0 paciente é avaliado trimestralmente por meio de exame visual, com a intenção de observar se a restauração permanece íntegra. Passados 12 meses, a restauração permanece no local e o dente não apresenta fratura ou sinais de comprometimento pulpar. Este tratamento demonstrou-se, até então, efetivo para a afecção dentária encontrada, pois a restauração preservou o elemento dental e, até o momento, preveniu fratura e comprometimento apical. Este tipo de tratamento também apresenta um benefício em relação ao custo, pois se torna mais acessível do que a extração dental.

Palavras-chave: Cárie. Infundíbulo. Restauração. 